\title{
Article
}

\section{Evaluasi Kebijakan Pemerintah Republik Indonesia Dalam Pelaksanaan (Replanting) Perkebunan Kelapa Sawit di Dusun Lembah Kuamang Tahun 2019}

\author{
Ronal Dison ${ }^{*}$, Dewi Wulansari ${ }^{2}$
}

This article is an open access article distributed under the terms and conditions of the Creative Commons Attribution-ShareAlike 4.0 International (CC BY SA ) License (https://creativecommo ns.org/licenses/bysa/4.0/).

\section{Jurnal Politik dan} Pemerintahan Daerah ISSN 2686-2271

Fakultas Ilmu Sosial dan Ilmu Politik, Universitas Muara Bungo Jl. Diponegoro No. 27, Muara Bungo-Jambi, (0747) 323310

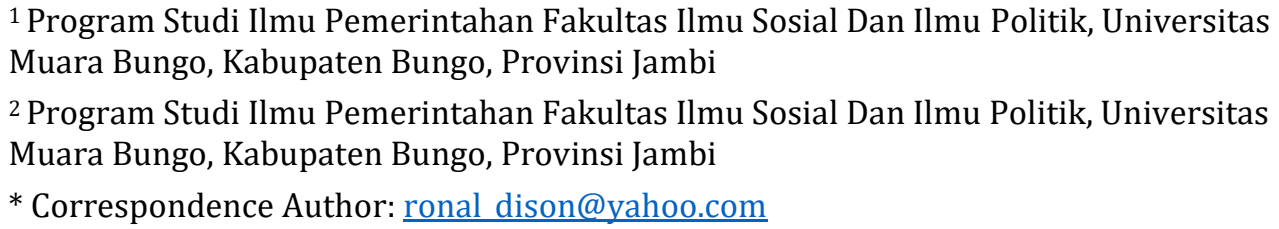

Abstract: In English, evaluation comes from the word evaluation. Thus, evaluation is defined as an assessment stage that is shown to the object of evaluation, to find out the state of an object by using an instrument and the results are described in the form of information. This study aims to determine the evaluation of the policies of the government of the republic of Indonesia in the implementation (replanting) of oil palm plantations in Lembah Kuamang, Pelepat Ilir District, Bungo Regency. Replanting is replanting (similar plants or previous plants) on the grounds that the original plant is too tall so it is difficult to harvest, it is too old or its productivity is considered low, and the type of plant still has good prospects. In the implementation of the rejuvenation of oil palm plantations using grant funds from the Palm Oil Plantation Fund Management Agency which is managed by the Village Unit Cooperative. Based on presidential regulation number 18 of 2016 concerning the implementation (replanting) of oil palm plantations. To manage funds for oil palm plantations, there is a presidential regulation number 61 of 2015 concerning the collection of funds in the management of funds for oil palm plantations. In the implementation of the replanting of oil palm plantations in the Kuamang valley village, it is not realized properly which is contained in article 4 paragraph 1 which reads: (a) labor (b) materials and tools. This data collection was carried out by observing and interviewing several informants related to the implementation (replanting) of oil palm plantations in the Kuamang valley in 2019. The data obtained from the study were analyzed using qualitative methods by comparing data related to the results of field observations. The types of data used are primary data and secondary data. The technique of taking informants in this research is by using purposive sampling technique. Due to non-participant research, the analysis approach uses the theory of William N, Quaden. Geographically, the hamlets of the Kuamang Valley are 1020, 38 East Bujung and 1600 South Latitude. The obstacles in the implementation (replanting) of oil palm plantations in the Kuamang valley in 2019 were the workforce where communication was lost to contractors in the rejuvenation of oil palm plantations with village unit cooperatives and the damage to the exsepator tool for working on oil palm plantations. Which is contained in Article 4 paragraph 1 which has not been realized properly in the village of Kuamang Valley. Efforts are being made to provide a letter to the contractor, to terminate the contract to the operator. If the community's oil palm seeds die, the village unit cooperative provides the seeds to the community using their own money.

Keywords: government policy of the republic of Indonesia, implementation of replanting. 


\begin{abstract}
Abstrak: Dalam bahasa inggris Evaluasi berasal dari kata evaluation. Dengan demikian, evaluasi diartikan sebagai sebuah tahapan penilaiaan yang ditunjukan kepada objek evaluasi, untuk mengetahui keadaan suatu objek dengan dengan menggunakan instrumen dan hasilnya dideskripsikan dalam bentuk informasi. Penelitian ini bertujuan untuk mengetahui evaluasi kebijakan pemerintah republik Indonesia dalam pelaksanaan (replanting) perkebunan kelapa sawit didusun Lembah Kuamang Kecamatan Pelepat Ilir Kabupaten Bungo. Peremajaan (replanting) adalah menanam kembali (tanaman sejenis atau tanaman sebelumnya) dengan alasan tanaman asal sudah terlalu tinggi sehingga sulit untuk dipanen, terlalu tua atau produktivitasanya dianggap rendah, dan jenis tanaman masih memiliki prospek yang baik. Dalam pelaksanaan peremajaan perkebunan kelapa sawit menggunakan dana hiba dari Badan Pengelolahan Dana Perkebunan Kelapa Sawit yang dikelolah oleh pihak Koperasi Unit Desa. Berdasarkan peraturan presiden nomor 18 tahun 2016 tentang pelaksanaan (replanting) perkabunan kelapa sawit. Untuk mengelolah dana perkebunan kelapa sawit terdapat dalam peraturan presiden nomor 61 tahun 2015 tentang penghimpunan dana dalam pengelolahan dana perkebuan kelapa sawit. Dalam pelaksanaan replanting perkebunan kelapa sawit didusun lembah kuamang tidak terealisasi dengan baik yang mana terdapat dalam pasal 4 ayat 1 yang berbunyi: (a) tenaga kerja (b) bahan dan alat. Pengumpulan data ini dilakukan dengan observasi dan wawancara dengan beberpaa informan yang berkaitan dengan pelaksanaan (replanting) perkebunan kelapa sawit didusun lembah kuamang tahun 2019. Data yang diperoleh dari penelitian di analisis menggunakan metode kualitatif dengan membandingkan data terkait dengan hasil observasi dilapang. Jenis-jenis data yang digunakan yaitu data primer dan data sekunder. Teknik pengambilan informan dalam penelitian ini adalah dengan memakai teknik purposive sampling. Karena penelitinan non partisipan, maka pendekatan analisisnya menggunakan teori Wiliam N, Quaden. Secara geografis dusun lembah kuamang 1020, 38 Bujung Timur dan 1600 Lintang Selatan. Adapun kendala dalam pelaksanaan (replanting) perkebunan kelapa sawit didusun lembah kuamang tahun 2019 adalah tenaga kerja yang mana terputusnya komunikasi kepada pihak kontaraktor dalam peremajaan perkebunan kelapa sawit dengan pihak koperasi unit desa dan rusaknya alat exsepator untuk pengerjaan lahan perkebunan kelapa sawit. Yang mana terdapat dalam pasal 4 ayat 1 yang belum teralisasi dengan baik di dusun lembah kuamang. Upaya yang dilakukan adalah memberikan surat kepada pihak kontaraktor, memutuskan kontrak kepada pihak operator, apabila bibit sawit masyarakat ada yang mati maka pihak koperasi unit desa memberikan bibit kepada masyarakat dengan menggunakan uang mandiri/uang sendiri.
\end{abstract}

Kata kunci: kebijakan pemerintah republik Indonesia, pelaksanaan replanting.

\title{
Pendahuluan
}

Pertumbuhan perekonomian Indonesia sepanjang tahun 2017 termasuk salah satu yang tinggi didunia. Sektor pertanian menjadi urutan teratas yang mampu mendongkrak pertumbuhan perekonomian Indonesia terutama dibidang perkebunan. Kelapa sawit yang menjadi andalan disektor perkebunan tentunya juga mendapatkan perhatian pemerintah terutama perkebunan rakyat. Kebutuhan minyak kelapa sawit akan semakin besar, sejalan dengan perkembangan jumlah penduduk dunia dan tingkat kesejahteraan penduduk. Oleh karenanya, tak heran bila perkebunan kelapa sawit di Indonesia cukup luas. Bisnis sawit membawa 
berkah bagi petani dan perekonomian lokal. Kelapa sawit merupakan merupakan tanaman yang sangat penting keberadaannya dalam kebermanfaatannya sebagai minyak nabati yang selanjutnya dapat diolah menjadi berbagai macam hal seperti produk makanan, minyak nabati maupun bahan bakar nabati (Hutasoit et al., 2015).

Di Muara Bungo, berdiri Koperasi Unit Desa (KUD) dengan pendapatan Rp 8 miliar pada tahun 2016. Kesuksesan ini tidak terlepas dari pertumbuhan pendapatan petani sawit di wilayah tersebut. Kuamang Kuning terdapat 19 unit pemukiman sekarang menjadi dusun. Di setiap unit berdiri Koperasi Unit Desa (KUD). Ada tiga kecamatan di Kuamang Kuning antara lain Kecamatan Pelepat Ilir, Kecamatan Pelepat dan Kecamtan Limbur termasuk Kabupaten Bungo.

Kegiatan peremajaan kelapa sawit (replanting) dilakukan dengan mengganti pohon kelapa sawit yang berusia 20-25 tahun yang hasil produksinya tidak sebaik pohon kelapa sawit yang baru (Saputri \& Syafrizal, 2018). Pedomaan pelaksanaan peremajaan perkebunan kelapa sawit dalam kerangka pembiayaan oleh BPDPKS (Badan Pengelolaan Dana Perkebunan kelapa Sawit) (Pemerintah Republik Indonesia, 2015). Lembaga yang merupakan unit organisasi noneselon dibidang pengelolaan dana perkebunan kelapa sawit yang berada di bawah dan bertanggung jawab kepada mentri keuangan melalui seketaris jendral. Yang mana BPDPKS bertugas mengelolah perkebunan kelapa sawit dana pembangunan sesuai dengan kebijakan yang ditetapkan oleh mentri keuangan dan berdasarkan undang-undang. Yang terdapat dalam peraturan presiden nomor 61 tahun 2015 tentang penghimpunan dan pengelolahan dana perkebunan kelapa sawit. BPDPKS ( Badan pengelola dana perkebunan kelapa sawit) akan mengelokasikan sejumlah dana untuk menjalankan program peremajaan (replanting) lahan perkebunan milik petani sawit. Para petani yang ingin mangajukan permohonan bantuanan replanting harus memenuhi lima persyaratan yang diberikan oleh BPDP. Bantuan dana uatama yang diberikan kepada para petani sawit yang memiliki lahan kurang dari empat hektar. Persyaratan yang harus dipenuhi yaitu sebagai berikut (Hakim \& Suherman, 2018).

1. Pengajuan dari koperasi ke BPDP.

2. Berkelompok kurang lebih 300 hektar.

3. Masuk dalam koperasi dan selanjutnya koperasi yang mengurus ke bank.

4. Lahan sawit yang akan ditanami ulang harus berpotensi dapat menghasilakan sawit yang berkualitas.

5. BPDP hanya menyalurkan bantuan kepada mereka yang memiliki lahan dengan jaminan kualitas hasil sawit cukup baik.

Dari lima persyaratan tersebut harus di lengkapi untuk pengambilan dana peremajaan perkebunan kelapa sawit supaya berjalan dengan lancar dalam pengambilan dana tersebut. Yang mana persyaratan tersebut harus dilengkapi oleh pihak Koperasi Unit Desa (KUD) Citra Markadi dusun lembah kuamang dan segera diberikan oleh dinas pertanian yang menagani bagian replanting perkenbunan kelapa sawit.

Kegiatan peremajaan ulang perkebunan sawit juga harus memperhatikan kondisi letak geografis perkebunan kelapa sawit tersebut. Pada program peremajaan (replanting) perkebunan kelapa sawit rakyat ini. BPDPKS turut membantu pembiayaan dana hibah sebesar 25.000.000 per hektare, tumbang sari dan bibit oleh mentri pertanian, selain itu juga didanai oleh perbankan nasional.

Pelaksanaan peremajaan (replanting) yang dilakukan pertama kali di dusun lembah kuamang pada tahun 2018 yang didanai oleh dana hiba BPDPKS tersebut dilakukan pada lahan seluas 110 hektare yang ikut mendaftaran 51 petani sawit, dalam pelaksanaan peremajaan (replanting) di dusun lembah kuamang ada dua orang petani sawit yang mengundurkan diri dalam pelaksanaan peremajaan 
replanting perkebunan kelapa sawit dikarenakan dalam pengerjaan replating perkebunan kelapa sawit membutuhkan waktu yang cukup lama. Didusun lembah kuamang dalam pelaksanaan peremajaan (replanting) terdapat lahan yang harus dikerjakan 104 hektare yang melibatkan 49 petani sawit yang menerima bantuan tersebut. Yang mana pihak dari Koprasi Unit Desa (KUD) tidak membatasi masyarakat dusun lembah kuamang untuk mendaftar peremajaan (replanting) perkebunan kelapa sawit. Tetapi pihak Koperasi Unit Desa (KUD) citra makardi membatasi luas tanah masyarakat yang ikut dalam mendaftar peremajaan replanting perkebunan kelapa sawit hanya boleh empat hektare tidak boleh lebih.

Dana yang diberikan BPDPKS akan digunakan untuk menunjang tahap pelaksanaan peremajaan termasuk biaya pembersihan lahan, penyewaan excavator, membeli bibit sawit, biaya tanam dan biaya pemeliharaan, sumber dana dapat berasal dari dana sendiri, pinjaman perusahaan inti atau pinjaman dari bank. (ibid) Kredit bank saat ini adalah Kredit Usaha Rakyat (KUR) khusus untuk perkebunan. Pemerintah menyediakan sklim kredit KPEN-PR yakni kredit yang diberikan dalam rangka mendukung program pengembangan tanaman bahan baku bahan bakar nabati dan program revitalisasi pertanian untuk peluasan, rehabilitas dan peremajaan tanaman kelapa sawit. Pihak BNI akan memeberikan pinjaman kepada petani selama petani tersebut tidak memiliki kredit yang buruk ataupun masuk dalam daftar blacklist bank. ibid

Para petani kelapa sawit yang bergabung di Koperasi Unit Dusun (KUD) Citra Markardi, khususnya di dusun Lembah Kuamang, Kecamaan Pelepat Ilir, Kabupaten Bungo, mendapatkan bantuan pelatihan, pendampingan kegiatan operasional dan pembiayaan. Bantuan tersebut datang dari BPDPKS (Badan Pengelolahan Dana Perkebunan Kelapa Sawit). Tujuannya para petani dapat memperoleh produktivitas sawit rakyat lebih tinggi dari sebelum di remajakaan. Dengan adanya peremajaan kelapa sawit di lembah kuamang sangat membantu perekonomian masyarakat petani sawit dan meningkatakan pendapatan hasil daerah di kabupaten bungo, pada tahun 2018 pendapatan asli daerah sebesar Rp. 134,3 miliar, sementara pada tahun 2019 pendapatan asli daerah sebesar Rp. 16,9 miliar.

Dalam pelaksanaan peremajaan perkebunan kelapa sawit dikabupaten bungo untuk pemeula telah mendapatkan dana hiba dari BPDPKS ynag berguna untuk meremajakan perkebunan kelapa sawit. Pemerintah melalui BPDPKS memberikan manfaat dana bagi hasil pajak CPO (Crude Palm Oil) (bppd, 2019). Yang mana di kabupaten bungo mempunyai target pelaksanaan replanting tahun 2018 ini 1.465 hektare, yang terdapat di Kecamatan Pelepat Ilir di KUD Mulya Mukti, KUD Citra Makardi, Kecamatan Pelepat di KUD Sumber Usaha Kita, KUD Insu Mudung dan Kecamatan Limbur di KUD Darma Bakti. Yang mana itu semua baru mengikuti pelaksanaan peremajaan perkebunan kelapa sawit tahap pertama. Adapun data tentang koperasi unit desa di kabupaten bungo sebagai berikut:

Tabel 1 Tentang Pelaksanaan (Replanting) Perkebunan Kelapa Sawit Di Lembah Kuamang Kecamatan Pelapat Ilir Kabupaten Bungo Pada Tahun 2019

No Nama koperasi unit desa (KUD)

1. Kecamatan Pelepat Ilir

Sari Mukti

Citra Markardi

2. Kecamatan pelepat

Sumber Usaha Kita

Insu madung

3. Kecamatan limbur

Darma Baktin

Luas

67,8656 На

110,1556 На

$52,8788 \mathrm{Ha}$

$102,3319 \mathrm{Ha}$

$60,6431 \mathrm{Ha}$

Sumber data ini didapatkan dari dinas pertanian yang bertanggung jawab dalam pelaksanaan peremajaan (replanting) perkebunan kelapa sawit di 
kabupaten bungo. Yang mana di jelaskan di atas ada tiga kecamatan di kabupaten bungo yang ikut dalam pelaksanaan peremajaan (replanting) perkebunan kelapa sawit. Setiap kecamtanan yang memiliki luas tanah yang berbeda, yang mana di pelapat ilir terdapat dua dusun yang ikut dalam pelaksanaan peremajaan perkebunan kelapa sawit terdapat di dusun lembah kuamang yang koperasi unit desa (KUD) citra markadi dan dusun mulya bahakti yang koperasi unit desa (KUD) sari mukti.

Kegiatan perdampingan meliputi pembinaan pengelolaan administrasi perkoperasian, penyiapan lahan, penggunaan bibit kelapa sawit unggul, menajemen budidaya sawit terbaik dan berkelanjutan. Hal tersebut diatur dalam Peraturan Mentri Pertanian Republik Indonesia Nomor: 18 Tahun 2016 tentang pedoman peremajaan perkebunan kelapa sawit (Pertanian, 2016). Yang berbunyi: Pasal 1 Peraturan Menteri ini dimaksudkan sebagai acuan dalam pembinaan, pemberian pelayanan dan pengembangan UsahaPerkebunan Kelapa Sawit secara efisien dan berkelanjutan melalui Peremajaan kebun kelapa sawit.

Pasal 2 Kegiatan Peremajaan Perkebunan Kelapa Sawit sebagaimana dimaksud dalam Pasal 1, meliputi:

a. Teknik Peremajaan kelapa sawit, antara lain pembukaan/pembersihan lahan, pengadaan benih, penanaman, pemupukan dan pemeliharaan tanaman kelapa sawit terintegrasi dapat dengan tanaman tumpang sari untuk periode Tanaman Belum Menghasilkan (TBM).

b. Pengembangan kelembagaan pekebun, antara lain pelatihan tenaga pendamping dan pekebun, penguatan organisasi, manajemen dan tata kelola Kelompok Tani/Gabungan Kelompok Tani/Koperasi, peningkatan kerjasama, dan kemitraan usaha dan unsur pendukung, antara lain pemetaan, Surat Tanda Daftar Usaha Perkebunan untuk Budi daya (STD-B), surat pernyataan pengelolaan lingkungan, sertifikasi lahan dan sertifikasi ISPO bagi yang memenuhi syarat sesuai aturan perundang-undangan.

Pasal 3 Kegiatan Peremajaan Perkebunan Kelapa Sawit, sebagaimana dimaksud dalam Pasal 2, dilakukan sesuai pedoman seperti tercantum dalam Lampiran yang merupakan bagian tidak terpisahkan dari Peraturan Menteri ini.

Pasal 4 (1) Komponen Peremajaan Perkebunan Kelapa Sawit sebagaimana dimaksud dalam Pasal 2, meliputi:

a. tenaga kerja;

b. infrastruktur; dan

c. bahan dan alat.

(2) Rincian komponen sebagaimana dimaksud pada ayat (1) ditetapkan sesuai dengan ketentuan peraturan perundang-undangan.

Pasal 5 Pendanaan Peremajaan Perkebunan Kelapa Sawit dapat bersumber dari pemerintah, pelaku usaha perkebunan, dan sumber dana lainnya sesuai dengan ketentuan peraturan perundang-undangan. Pasal 6 Peremajaan Perkebunan Kelapa Sawit dapat dilakukan dengan melanjutkan pola kemitraan yang telah ada maupun pola lainnya dalam hubungan yang saling menguntungkan, saling menghargai, saling bertanggung jawab, saling memperkuat dan saling ketergantungan. Pasal 7 Peraturan Menteri ini mulai berlaku pada tanggal diundangkan. Agar setiap orang mengetahuinya, memerintahkan.

Yang mana dari undang-undang mentri pertanian nomor 18 tahun 2016 tentang pelaksanaan peremajaan (replanting) perkebunan kelapa sawit didusun lembah kuamang tidak terealisasi dengan baik yang mana tidak mengikuti prosedur dalam peraturan undang-undang tersebut yang terdapat dalam pasal 2 ayat b dan c, pasal 4 ayat a dan c, dan pasal 6. Dari pasal 2 ayat b dan c yang menjelaskan jenis kegiatan dalam pelaksanaan (replanting) perkebunan kelapa sawit sebagai berikut: 
Pasal 2 ayat b tidak terlaksananya dalam pelaksanaan replanting perkebunan kelapa sawit didusun lembah kuamang bawasanya pihak koperasi unit desa tidak berkerja sama dengan pihak lain seharusnya dalam pelaksanaan replanting harus peningkatkan kerja sama dengan pihak lain dan tidak adanya kerjasama dengan kelompk tani, didusun lembah kumang tidak adanya kerja sama dengan pihak lain kecuali kerja sama dengan pemerintah pusat yang mana dalam penjualan buah tandan sawit pihak Koperasi Unit Desa tidak menampung sawit tersebut.

Pasal 2 ayat c bawasanya tidak terlaksanaanya dalam pelaksanaan replanting perkebunan kelapa sawit didusun lembah kuamang yang mana dalam pihak Koperasi Unit Desa waktu bersosialisasi dengan masyarakat hanya mengatakan persyaratan untuk ikut dalam pelaksanaan peremajaan perkebunan kelapa sawit sebagai berikut:

a. Harus membawa foto kopi kartu keluarga.

b. Foto kopi KTP.

c. Foto kopi surat nikah.

d. Sertifikat jual beli/hibah dan pas foto $3 \times 4$.

e. Dikumpulkan di setiap KUD masing-masing dan umur kelapa sawit produksinya sudah diatas 25 atau 20 tahun, walaupun hasil produksinya rendah diperbolehkan untuk ikut replanting.

Yang mana dalam persyaratan tersebut yang harus dilengkapin oleh masyarakat yang seharusnya dalam pendaftaran tersebut setiap masyarakt harus memiliki surat tanda dalam usaha perkebunan untuk budi daya (STD-B), dalam pelaksanaan tersebut tidak mengikuti prosedur undang-undang yang sudah ada.

Pasal 4 ayat 1 (a) tenaga kerja bahwasanya dalam pelaksanaan peremajaan perkebunan kelapa sawit didusun lembah kuamang tidak terealisasi dengan baik yang mana lambatnya dalam penanganan lahan pelaksanaan peremajaan perkebunan kelapa sawit, dalam pelaksanaan peremajaan perkebunan kelapa sawit di laksanakan pada bulan Desember 2018 sampai Desember 2019 tetapi dalam pelaksanaan peremajaan perkebunanan kelapa sawit pada bulan Mei 2019 mulai berhenti pengerjaan secara total dan tidak adanya sosialisasi pihak koperasi unit desa ke pada masyarakat. Sampai saat ini tidak adanya keputusan dari pihak kontraktor kepada masyaratkat petani sawit di dusun lembah kuamang tersebut dan tidak adanya komunikasi operator kepada pihak koperasi unit desa (KUD) Citra Markardi.

Yang mana terbengkalainnya lahan para masyarakat petani sawit yang membuat petani menunggu cukup lama. Dengan berhentinya tenaga kerja membuat masyarakat bingung dalam keadaan ini, tidak adanya konfermasi pihak KUD (koperasi unit desa) kepada masyarakat petani sawit secara terus terang membuat masyarakat menjadi bingung.

Pasal 4 ayat 1 yang berbunyi: (b) barang dan alat yang menjelaskan tentang bahan dan alat yang digunakan dalam pelaksanaan peremajaan perkebunan kelapa sawit, dalam ayat 1 tersebut yang tidak terealisasi dengan baik. Yang mana dalam kebijakan tersebut tidak sesuai dengan yang diharapkan oleh para masyarakat, yang terdapat permasalahan dengan alat untuk pengerjaan pada lahan peremajaan perkebunan kelapa sawit dilembah kuamang.

Seperti alat excsevator yang rusak dan dari pihak koperasi unit desa hanya bisa menunggu sampai alat excavator diperbaiki, sampai saat ini pihak dari koperasi unit desa masih berusaha untuk mencari jalan keluarnya. Dengan rusaknya alat excavator membuat lahan petani terbenkalai dan membuat petani resah dikarenakan bibit sawit yang semakin hari semakin tumbuh besar sedangkan lahan yang untuk ditanam belum tersedia, sebagian lahan petani sudah ada yang ditanami bibit sawit, sebagian petani masih menunggu untuk dikerjakan lokasi tersebut. 
Dengan lahan seluas 104 hektare pihak KUD hanya menggerakan empat alat excavator, didalam perkerjaan tersebut dibagi menjadi tiga Pokja (kelompok kerja) yaitu kelompok kerja I yang berjumlah 22 orang, kelompok kerja II yang berjumlah 12 orang dan kelompok kerja III yang berjulah 15 orang setiap kelompok kerja memiliki tanggung jawab terhadap kelompoknya masing-masing, apabila ada keluhan dalam pelaksanaan peremajaan perkebunan kelapa sawit masyarakat melaporkan kepada ketua kelompok kerja masing-masing yang mana nantinya ketua kelompok akan melaporkan keluhan masyarakat kepada ketua koperasi unit desa (KUD) Citra Markadi. Adapun masyarakat yang mengeluh kepada ketua kelompok kerja tetapi ketua kelompok kerja hanya bisa menjelaskan kepada masyarakatnya bahwasannya alat yang digunakan untuk replanting rusak.

Yang mana disetiap lahanan hanya ada dua exsepator, sedangkan dalam berkerjanya excavator dilahan membutuhkan waktu tiga hari dalam dua hektare. Sebagaian para petani sawit menanamkan bibitnya diperkarangan lahan yang lain sebab dari beberapa bulan ini para petani sudah mengambil bibit sawit yang cukup banyak sekisar 140 perhektare bibit tersebut sampai saat ini sudah tumbuh besar dan belum juga di tanamkan akhirnya para petani mengambil langkah untuk menanamkan sawit tersebut dilahan lain, adapun sebagian sawit petani yang mati dan pihak KUD menyediakan bibit yang baru tetapi petani sawit harus membeli bibit tersebut dengan uang sendiri.

Yang mana bahwa bibit kelapa sawit siap tanam benar-benar tersedia pada saat replanting dilaksanakan. Bibit yang siap ditanam jumlahnya harus cukup dan kualitasnya baik. Selain bibit sawit yang dikasih oleh pihak pemerintah pupuk dan pagar setenlis pun sudah diberikan. Adapun dalam mengerjakan pelaksanaan perkebunan kelapa sawit dilihat dari lahan petani sawit seperti tanah rawa dan tanah gambut yang membuat pihak operator harus lebih hati-hati dalam penangannya tersebut yang bisa menyebabkan exsepator rusak. Hal tersebut yang menyebabkan lamanya dalam menangani lahan rawa/gambut. Yang mana dari kebijakan pemerintah tersebut yang belum terealisasi dengan baik di dusun lembah kuamang dalam pelaksanaan peremajaan (replanting) perkebunan kelapa sawit.

\section{Pembahasan}

\section{Evaluasi Kebijakan Pemerintah RI Dalam Pelaksanaan (Replanting) Perkebunan Kelapa Sawit Didusun Lembah Kuamang}

Evaluasi berkenaan dengan produksi informasi mengenai nilai atau manfaat hasil kebijakan. Evaluasi memberi informasi yang valit dan dapat dipercaya mengenai kinerja kebijakan yaitu seberapa jauh kebutuhan, nilai, dan kesempatan telah dicapai melalui tindakan publik. Evaluasi kebijakan berkenaan pada kinerja dari kebijakan, khususnya implementasi kebijakan publik Wiliam N. Dunn (2003:608-610). Dalam hal ini telah ditetapkan dalam peraturan mentri pertanian nomor 16 tahun 2016 tentang pedoman pelaksanaan peremajaan perkebunan kelapa sawit. Pelaksanaan peremajaan perkebunan kelapa sawit didusun lembah kuamang baru pertama kali diadakan pada Desember 2018 sampai Desember 2019. Yang mana dalam pelaksanaan peremajaan perkebunan kelapa sawit tidak sesuai dengan undang-undang yang telah ditetapkan. Dalam pelaksanaan (replanting) perkebunan kelapa sawit didusun lembah kuamang yang berkerja sama dengan pihak Koperasi Unit Desa (KUD) Citra Markadi yang didanai oleh dana hiba BPDKS (Badan Pengolahan Dana Perkebun Kelapa Sawit) sebesar 25.000.000 dalam satu hektar.

Didalam pelaksanaan peremajaan perkebunan kelapa sawit pemerintah pusat memberi kewenangan kepada pihak koperasi unit desa (KUD) yang megelolah pelaksanaan tersebut yang mana pemerintah pusat hanya memantau perkembangan pelaksanaan peremajaan perkebunan kelapa sawit didusun lembah kumang kecamatan pelepat ilir kebupaten bungo. Didusun lembah kuamang 
memiliki luas tanah yang harus direplanting seluas 104.1536 hektate dengan jumlah masyarakat yang ikut serta 49 orang setiap masyarakat memiliki luas tanah yang berbeda.

Dengan adanya kebijakan ini membudahkan para masyarakat petani sawit untuk mendapatkan produksi sawit yang berkualitas dan membuat hasil panen yang berton-ton yang mengakibatkan naiknya pendapantan asli daerah kabupaten bungo. Pada saat sawit sudah mulai panen pihak masyarakat petani sawit menjual buah tandan sawit ketengkulang sawit masing-masing, dikarnakan pihak koperasi unit desa (KUD) tidak mau menampung buah tandan sawit tersebut, karena pihak koperasi unit desa (KUD) Citra Markadi tidak berkerja sama dengan PT Sawindo maupun tengkulak kelompok tani.

Adapun data setiap dusun yang ikut serta dalam pelaksanaan peremajaan perkebunan kelapa sawit di kabupaten bungo sebagai berikut:

Tabel 2. Tentang Pelaksanaan (Replanting) Perkebunan Kelapa Sawit Di Dusun Lembah Kuamang Kecamatan Pelapat Ilir Kabupaten Bungo Tahun 2019.

\begin{tabular}{l|l|r|r} 
No & \multicolumn{1}{|c|}{$\begin{array}{r}\text { Nama Koperasi Unit Desa } \\
\text { (KUD) }\end{array}$} & $\begin{array}{r}\text { Belum Terealisasi } \\
\text { Ha }\end{array}$ & \multicolumn{1}{c}{$\begin{array}{c}\text { Luas } \\
\text { Ha }\end{array}$} \\
1. & $\begin{array}{l}\text { Kecamatan Pelepat Ilir } \\
\text { Sari Mukti }\end{array}$ & 67,8656 & 67,8656 \\
& Citra Markadi & 103 & 110,1556 \\
2. & Kecamatan Pelepat & & \\
& Sumber Usaha Kita & 48,7161 & 52,8788 \\
3. & Insu madung & 152,3319 & 102,3319 \\
& Kecamatan Limbur & 60,6431 & 60,6431
\end{tabular}

Data diatas didapatkan dari hasil wawancara dari Bapak Yadi Saputra S.Hut sebagai dinas pertanian yang bertanggung jawab atas pelaksanaan peremajaan perkebunan kelapa sawit di kebupaten bungo, dapat diketahui bahwa di kabupaten bungo yang ikut dalam pelaksanaan peremajaan (replanting) perkebunan kelapa sawit ada tiga kecamatan pelepat ilir, kecamatan pelepat dan kecamatam limbur, ada lima KUD (koperasi unit desa) seperti Sari Mukti, Cintra Markadi, Sumber Usaha Kita, Insun Madung, Darma Baktin, setiap kecamatan memiliki luas tanah yang berbeda. Khusunya untuk dusun lembah kuamang yang mendaftar dalam pelaksanaan peremajaan perkebunan kelapa sawit sebanyak 51 orang dengan luas lahan 110,1556 adapun sebagian masyarakat yang mengundurkan diri dalam pelaksanaan peremjaaan perkebunan kelapa sawit yang berjumlah dua orang yang memiliki luas tanah 6.002 hektare. Dalam pelaksanaan peremajaan perkebunan kelapa sawit didusun lembah kuamang yang di laksanakan dengan luas tanah 104.1536 hektare yang berjumlah 49 orang.

Yang mana dalam pelaksanaan peremajaan perkebunan kelapa sawit mengunakan dana hiba sebesar Rp.25.000.0000, pemerintah melalui BPDPKS memberi manfaat dana hasil pajak CPO (Crude Palm Oil. Pemerintah desa hanya sebagai perantara dalam kegiatan peremajaan (replanting) perkebunan kelapa sawit didusun lembah kuamang supaya berjalan dengan baik dan pihak koperasi unit desa berkerja sama dengan kepala desa untuk mengumpulkan masyarakatnya supaya ikut dalam pelaksanaan peremajaan (replanting) perkebunan kelapa sawit dan untuk mendapatkan izin untuk bersosialisi dikantor desa dengan izin kepala desa maka pelaksanaan peremajaan perkebunan kelapa sawit terlaksana di dusun lembah kumang.

Pelaksanaan peremajaan (replanting) perkebunan kelapa sawit di mulai pada Desember 2018 sampai 2019 hal tersbut pertama kali di laksanakan di dusun 
lembah kuamang pada tahap pertama, yang dalam pelaksanaannya pihak koperasi unit desa tidak pernah membatasi masyarakat untuk ikut serta dalam pelaksanaan replanting tersebut tetapi hanya diperbolehkan luas lahanya empat hektare, di dusun lembah kuamang yang ikut serta dalam pelakasnaan replanting harus melengkapai persyaratanya seperti harus membawa foto kopi kartu keluarga foto kopi KTP dan legalisasi lahan dikumpulkan di setiap KUD masing-masing dan umur kelapa sawit produksinya sudah diatas 25 atau 20 tahun, walaupun hasil produksinya rendah diperbolehkan untuk ikut replanting perkebunan kelapa sawit. Yang mana masyarakatnya harus melengkapai persyaratan tersebut, yang sudah ikut mendaftar sebanya 49 orang dengan luas lahan 104 hektare yang masingmasing masyarakat memiiki luas lahan yang berbeda. Yang mana dengan adanya kebijakan dari pemerintah sangat mebantu masyarakat dalam meningkatkan perekonomian.

Dalam pelaksanaan peremajaan (replanting) perkebunan kelapa sawit di lembah kuamang. Dalam pelaksanaan peemajaan (replanting) dengan luas lahan 104.1536 setiap orang memiliki luas tanah yang berbeda, yang ikut mendaftar sebanyak 49 orang yang dibagi menjadi tiga kelompok kerja disetiap kelompok memiliki jumalah yang berbeda seperti kelompok pertama berjumlah 22 orang, kelompok kedua berjumlah 12 orang dan kelompok ketiga berjumlah 15 orang, setiap kelompok memiliki ketua yang bertangung jawab atas kelompoknya masingmasing.

Table 3. Tentang Rincian Dana Pelaksanaan (Replanting) Perkebunan Kelapa Sawit Di Dusun Lembah Kuamang Tahun 2019

No

1

2.

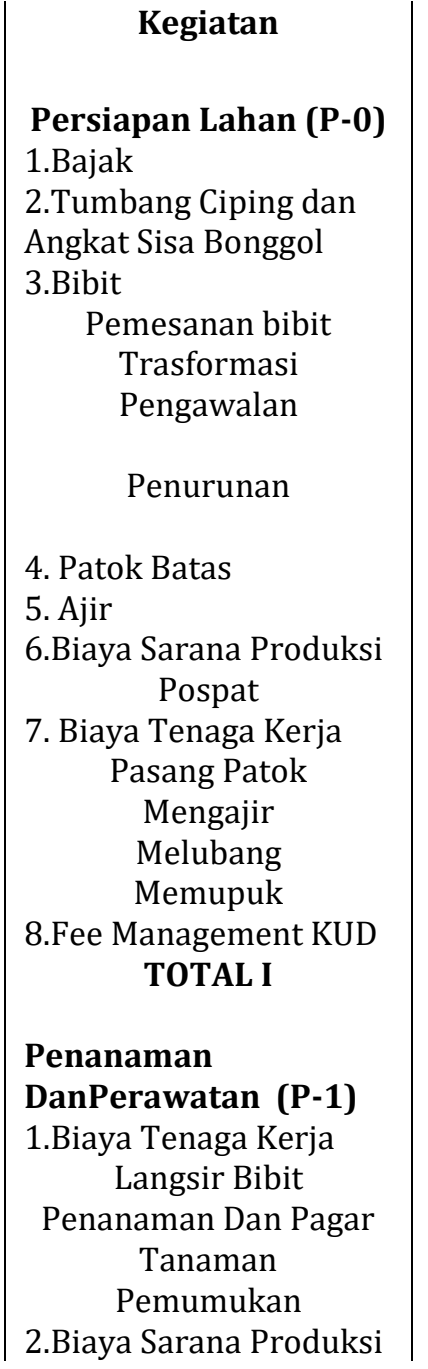

\begin{tabular}{c|c|}
\multicolumn{2}{c|}{ Volume } \\
Per Ha & Satuan \\
1 & \\
125 & Ha \\
& Ha \\
140 & Ha \\
140 & Ha \\
140 & Ha \\
140 & Ha \\
& Batang \\
4 & Batang \\
125 & \\
62,5 & Kg \\
4 & Batang \\
125 & Batang \\
125 & Lubang \\
2 & OH \\
0.05 & \\
& \\
& \\
140 & \\
125 & Batang \\
& \\
& \\
&
\end{tabular}
Harga Satuan

2.571 .000 .00 80.000 .00

38.000 .00

8.500 .00

2.500 .00

1.000 .00

25.000 .00

2.500 .00

2.900 .00

3.000 .00

3.000 .00

3.432 .00

80.000 .00

21.140 .750 .00

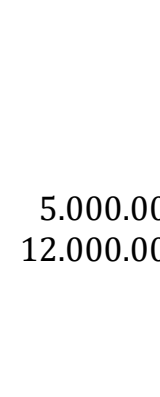

Biaya

2.571.000.00

10.000 .000 .0

5.320 .000 .00

1.190 .000 .00

350.000 .00

140.000 .00

100.000 .00

312.500 .00

181.250 .00

12.000 .00

375.000 .00

429.000 .00

160.000 .00

1.057.037.50

22.197.787.

50

700.000 .00

1.500 .000 .00 


\begin{tabular}{|c|c|c|c|c|}
\hline Dolomit & 250 & $\mathrm{Kg}$ & 1.500 .00 & 375.000 .00 \\
\hline Urea & 62 & $\mathrm{Kg}$ & 5.000 .00 & 310.000 .00 \\
\hline 3.Administrasi & 1 & $\mathrm{Ha}$ & 810.000 .00 & 810.000 .00 \\
\hline \multicolumn{5}{|l|}{ Perbankan } \\
\hline $\begin{array}{l}\text { 4. Free Manajemen KUD } \\
\text { TOTAL II }\end{array}$ & 0.05 & & 3.855 .000 .00 & $\begin{array}{r}192.750 .00 \\
\mathbf{4 . 0 4 7 . 7 5 0 . 0}\end{array}$ \\
\hline \multicolumn{5}{|l|}{ Perawatan (P-II) } \\
\hline Urea & 175 & $\mathrm{Kg}$ & 5.000 .00 & 875.000 .00 \\
\hline Pospat & 119 & $\mathrm{Kg}$ & 7.000 .00 & 833.000 .00 \\
\hline Mop & 144 & $\mathrm{Kg}$ & 6.000 .00 & 864.000 .00 \\
\hline Kieserite & 44 & $\mathrm{Kg}$ & 6.000 .00 & 264.000 .00 \\
\hline Insektisida & 1 & Liter & 60.000 .00 & 60.000 .00 \\
\hline Herbesida & 20 & Liter & 55.000 .00 & 1.100 .000 .00 \\
\hline \multicolumn{5}{|l|}{ 2.Biaya Tenaga Kerja } \\
\hline Pengendalian Gulma & 3 & Kali & 300.000 .00 & 900.000 .00 \\
\hline Memupuk & 6 & $\mathrm{OH}$ & 80.000 .00 & 480.000 .00 \\
\hline Membuka piringan & 125 & Batang & 6.800 .00 & 850.000 .00 \\
\hline Membuka gawangan & 1 & $\mathrm{Ha}$ & 500.000 .00 & 500.000 .00 \\
\hline Free manajemen KUD & 0,05 & & 6.726 .000 .00 & 336.300 .00 \\
\hline TOTAL III & & & & 7.062 .300 .0 \\
\hline \multirow{2}{*}{\multicolumn{5}{|c|}{$\begin{array}{c}\text { Perawatan (P-III) } \\
\text { 1.Biaya Sarana Produksi }\end{array}$}} \\
\hline & & & & \\
\hline Urea & 200 & $\mathrm{Kg}$ & 5.000 .00 & 1.000 .000 .00 \\
\hline Pospat & 200 & $\mathrm{Kg}$ & 7.000 .00 & 1.400 .000 .00 \\
\hline Mop & 350 & $\mathrm{Kg}$ & 6.000 .00 & 2.100 .000 .00 \\
\hline Kieserite & 50 & $\mathrm{Kg}$ & 6.000 .00 & 300.000 .00 \\
\hline Insektisida & 1 & Liter & 60.000 .00 & 60.000 .00 \\
\hline Herbesida & 20 & Liter & 55.000 .00 & 1.100 .000 .00 \\
\hline \multicolumn{5}{|l|}{ 2.Biava Tenaga Keria } \\
\hline Pengendalian Gulma & 3 & Kali & 300.000 .00 & 900.000 .00 \\
\hline Memupuk & 6 & $\mathrm{OH}$ & 80.000 .00 & 480.000 .00 \\
\hline Membuka piringan & 125 & Batang & 6.800 .00 & 850.000 .00 \\
\hline Membuka gawangan & 1 & $\mathrm{Ha}$ & 500.000 .00 & 500.000 .00 \\
\hline 3.Free manajemen KUD & 0,05 & & 8.690 .000 .00 & 434.500 .00 \\
\hline TOTAL IV & & & & 9.124 .500 .0 \\
\hline Grand Total & & & & 42.432 .337 \\
\hline & & & & \\
\hline Bantuan BPDPKS & & & & 25.000 .000 . \\
\hline & & & & 00 \\
\hline Selisih (biaya yang & & & & 17.432.337. \\
\hline $\begin{array}{l}\text { dihutangkan pada } \\
\text { bank) }\end{array}$ & & & & \\
\hline
\end{tabular}

Setiap masyarakat yang ikut dalam pelaksanaan peremajaan perkebunan kelapa sawit mendapatkan dana sebesar 25.000.000 perhektare. Yang mana uang tersebut di kelolah oleh pihak bendahara koperasi unit desa (KUD) untuk memenuhi kebutuhan masyarakatnya pihak koperasi unit desa menyiapkan seperti pupuk, pagar tanaman dan bibit sawit. Yang mana semua itu berasal dari dana hiba BPDPKS yang memberi kewenangan kepada bendahara koperasi unit desa (KUD) untuk mengelolah dana tersebut. Dalam pelaksanaan peremajaan perkebunan kelapa sawit berkerja sama dengan pihak BANK untuk mempermudahkan pengambilan uang, apabila uang tersebut bersisah maka harus dikembalikan ke pemerintah pusat. 
Masyarakat dusun lembah kuamang yang ikut serta dalam pelaksanaan peremajaan perkebunan kelapa sawit di dusun lembah kuamang, dengan adanya kebijakan pelaksanaan peremajaan perkebunan kelapa sawit sangat membatu dalam segi perekonomian dan memudahkan masyarakat untuk mendapatkan bibit yang berkualitas, dan mendapatkan pupuk dalam masa tanam. Adapun dalam pelaksanaan replanting perkebunan kelapa sawit tidak berjalan dengan maksimal yang membuat masyarakat bingung dalam menangani hal tersebut.

Masyarakat yang tidak ikut serta dalam pelaksanaan peremajaan perkebunan kelapa sawit dikarnakan dalam pelaksanaan peremajaan tersebut yang membutuhkan waktu cukup lama dan sawinya belum waktunya untuk di tumbang dikarnakan masih menghasikan buah sawit yang cukup bagus. Dan tidak adanya sosialisasi kemasyarakat disetiap setiap kampung. Yang mengakibatkan kurangnya informasi sebagian masyarakat dalam pelaksanaan replanting tersebut.

Kendala Pemerintah Koperasi Unit Desa (KUD) Dalam Pelaksanaan (replanting) Perkebunan Kelapa Sawit Didusun Lembah Kuamang Tahun 2019.

Dalam pelaksanaan peremajaan (replanting) perkebunan kelapa sawit didusun lembah kuamang yang tidak terealisasi dengan baik, yang mana terdapat dalam peraturan mentri petanian nomor 18 tahun 2016 tentang pedoman pelaksaan peremajaan perkebunan kelapa sawit yang terdapat dalam pasal 2, pasal 4 dan pasal 6. Dalam pelaksanaan peremajaan perkebunan kelapa sawit didusun lembah kuamang tidak sesuai prosedur yang di tetapkan oleh pedoman pelaksanaan replanting. Kompenen dalam pelaksanaan peremajaan perkebunana kelapa sawit sebagaimana dimaksud dalam pasal 2 , pasal 4 dan pasal 6 sebagai berikut:

a. Pasal 2 Ayat 2 yang berbunyi pengembangan kelembagaan pekebun, antara lain pelatihan tenaga pendamping dan pekebun, penguatan organisasi, manajemen dan tata kelola kelompok tani/gabungan kelompok tani/koprasi, peningkatkan kerjasama, dan kemitraan usaha.

Sebagaimana yang dijelaskan dalam pedoman peremajaan perkebunan kelapa sawit bawasanya didusun lembah kuamang tidak menerapkan seperti didalam peraturan perundang-undang yang mana didusun lembah kuamang dalam pelaksanaan peremajaan perkebunan kelapa sawit tidak adanya bergabung dengan kelompok tani atau tengkulak sawit dan tidak adanya kemitraan dalam pelaksanaan peremajaan tersebut. Yang mana dalam hasil panen buah tandan sawit masyarakat menjual kepada tengkulang masing-masing, yang seharusnya pihak koperasi unit desa berkerja sama dengan kelompok tani.

Yang mana pemerintah daerah yang memiliki kewenangan secara penuh dalam pelaksanaan peremajaan perekebunan kelapa sawit tersebut, yang mana pemerintah melalui BPDPKS (Badan Pengelolahan Dana Perkebunan Kelapa Sawit) memberikan manfaat dana bagi hasil pajak CPO (Crude Palm Oil). yang mana pihak pemerintah daerah yang berkerja sama dengan BPDPKS dari pajak tersebut yang mana minyak kelapa sawit tersebut yang bagi hasil dengan pemerintah daerah, yang mana dari bagi hasil pajak tersebut bisa memodali masyarakat supaya mendapatkan bibit yang berkualaitas hal ini yang yang membuat pemerintah daerah memberi kewenangan kepada masyarakat untuk mengelolah sawitnya sendiri. Yang mana dari masyarakat untuk masyarakat.

b. Pasal 2 Ayat 3 unsur pendukung, antara lain pemetaan, surat tanda daftar usaha perkebunan untuk budi daya (STD-B), surat pernyataan 
pengelolahan lingkungan, sertifikasi ISPO bagi yang memenuhi syarat sesuai aturan perundang-undang.

Sebagaimana yang sudah dijelaskan didalam pedoman pelaksanaan peremajaan perkebunan kelapa sawit ada unsur pendukung yang harus dipenuhi dalam pelaksanann replanting tersebut. Yang mana didusun lembah kuamang tidak sesuai dengan peraturan pedoman peremajaan replanting perkebunan kelapa sawit karena didalam aturan tersebut menjelaskan tentang STD-B (Surat Tanda Daftar Usaha Perkebunan Untuk Budi Daya) sedangkan masyarakat didusun lembah kuamang tidak mengurus surat tersebut dan dari pihak Koperasi Unit Desa waktu besosialisasi tidak menyampaikan hal tersebut.

c. Pasal 4 ayat 1 poin (a) tenaga kerja.

Dalam pelaksanaan kebijakan pemerintah yang tidak terealisasi dengan baik yang terdapat dalam pasal 4 ayat 1 yang berbunyi (a) tenaga kerja yang mejelaskan tentang tenaga kerja dalam pelaksanaan peremajaan perkebunan kelapa sawit di lembah kuamang. Yang mana lambatnya dalam penanganan lahan replanting perkebunan kelapa sawit, waktu bersosialisasi dengan masyarakat mengatakan bahwa Desember 2019 sudah selesai peremajaan perkebunan sawit tersebut. Pelaksanaan peremajaan perkebunanan kepala sawit di mulai pada Desember 2018 sampai Desember 2019 yang seharusnya pelaksanaan tersebut sudah selesai, pada bulan Mei 2019 pengerjaan berhentin secara total dikarnakan alat yang rusak, pihak kontaraktor dan operator tidak mau bertanggung jawab dalam hal tersebut yang membuat pihak koperasi unit desa (KUD) Citra Markadi menjadi bingung dalam mengangani hal tersebut, dikarnakan sudah terikat kontarak kepada kontraktor tersebut. Dengan berhentinya perkerjaan tersebut tidak adanya sosialisasi kepada masyarakat yang menimbulkan pertanyaan di setiap kelompok kerja. Dikarnakan lalainya dalam pengerjaan membuat lahan para masyarakat terbengakalai.

Ketua KUD (Koperasi Unit Desa) yang bertanggungjawab dalam pelaksanaan peremajaan (replanting) perkebunan kelapa sawit di dusun lembah kuamang. Yang mana dalam kendala tersebut yang telah disampaikan oleh ketua koperasi unit desa bahwasanya susahnya komunikasi terhadap pihak operator yang menangani dalam pelaksanaan peremajaan perkebunan kelapa sawit di dusun lembah kuamang, tidak adanya sosialisasi terhadap masyarakat petani sawit yang membuat masyarakat menjadi bingung dan tidak tepat waktunya dalam pelaksanaan peremajaan perkebunan kelapa sawit di dusun lembah kuamang. Tenaga kerja yang mengalami berhenti secara total dan putusnya komunikasi dari pihak operator ke pihak koperasi unit desa (KUD), yang mana pihak operator menyulitkan pihak koperasi unit desa (KUD) Citra Markadi yang telah berusaha untuk menghubungi pihak operator, tidak bertanggung jawabnya pihak operator terhadap pelaksanaan peremajaan perkebunan kelapa sawit didusun lembah kuamang, hal ini menyebabkan terbengkalainya lahan masyarakat dan membuat lamanya dalam sistem penanaman bibit sawit. Seharusnya pelaksanaan peremajaan perkebunan kelapa sawit sudah selesai pada Desember 2019. Pasal 4 ayat 1 poin (c) bahan dan alat 
Sedangkan kebijakan pemerintah yang tidak terealisasi dengan baik terdapat dalam pasal 4 ayat yang berbunyi: (b) barang dan alat yang menjelaskan tentang bahan dan alat yang digunakan dalam pelaksanaan peremajaan perkebunan kelapa sawit, dalam ayat 1 tersebut yang tidak terealisasi dengan baik. Yang mana tidak sesuai dengan peraturan program peremajaan perkebunan kelapa sawit, dalam pelaksanaan tersebut tidak sesuai dengan yang diharapkan oleh para masyarakat, yang terdapat permasalahan dengan alat untuk pengerjaan pada lahan peremajaan perkebunan sawit dilembah kuamang.

Dalam pelaksanaan yang tidak sesuai dengan dilapangan/lahan yang terdapat di alat yang tidak memadai dan membuat perkerjaan menjadi terbengkalai yang merugikan banyak petani. Rusak alat excepator membuat pekerjaan berhenti secara total dalam hal ini pihak koperasi unit desa sangat bingung dalam menghadapinya, dikarnakan pihak operator yang susah untuk dihubungi. Dengan rusaknya excavator membuat lahan masyarakat terbengkalai dan membuat masyarakat menjadi bingung dalam menanganinya di karnakan tidak adanya sosialisasi pihak koperasi unit desa kepada masyarakatntya. Yang mana masyarakat mengambil bibit sawit sebanyak 140 perhektare yang samapai saat ini belum juga di tanam.

Sedangkan yang membuat kendala dalam pelaksanaan peremajaan perkebunan kelapa sawit terdapat pada kerusakan alat berat (exsepator) yang membuat berhentinya dalam pengerjaan lahan di dusun lembah kuamang, yang mana tidak adanya sosialisasi kepada masyarakat dusun lembah kuamang, adapun adanya lahan yang dapat mempengaruhi kerusakan dalam alat berat (exsepator) tersebut seperti lahan gambut dan lahan rawa yang dapat menyebabkan kerusakan pada alat berat tersebut, di dusun lembah kuamang yang ikut serta dalam pelaksanaan peremajaan (replanting) perkebunan kelapa sawit sebagian lahan milik masyarakat tersebut adalah tanah rawa yang membuat pengerjaan sangat sulit dalam menagani hal tersebut di karenakan apabila alat berat (exsepator) sedang mengerjakan lahan rawa yang ditakutkannya alat tersebut masuk kedalam tanah rawa yang membuat alat tersebut menjadi rusak dan harus di tarik oleh alat berat lainya.

Ketua KUD koperasi unit desa yang bertanggungjawab dalam pelaksanaan peremajaan (replanting) perkebunan kelapa sawit di dusun lembah kuamang. Yang mana kendala yang terjadi dalam pelekasanaan peremajaan perkebunan kelapa sawit di dusun lembah kuamang seperti rusaknya alat excepator yang digunakan untuk membajak lahan. Dengan kerusakan alat tersbut membuat berhentinya pengerjaan lahan masyarakat secara total dan tidak adanya sosialisasi dari pihak Koperasi Unit Desa (KUD) kepada masyarakat yang membuat masyarakat menjadi binggung dengan kondisi tersebut. Yang mana berapa dari masyarakat yang ikut serta dalam peremajaan perkebunan kelapa sawit ini memiliki lahan rawa yang mengakibatkan para operator kesulitan dalam menangani hal tersebut.

d. Pasal 6 yang berbunyi peremajaan perkenunan kelapa sawit dapat dilakukan dengan menjutkan pola kemitraan yang ada maupun pola lainnya dalam hubungan yang saling menguntungkan, saling 
menghargai, saling bertanggungjawab, saling memperkuat dan saling ketergantungan.

Dalam pelaksanaan peremajaan perkebunan kelapa sawit didusun lembah kuamang seharusnya memiliki pola kemitraan terhadapan tengkulak lain yang mana yang sudah di tetapkan dalam pedoman replanting hal ini yang seharusnya diterapkan didusun lembah kuamang tetapi pihak koperasi citra markadi tidak mengikuti dalam pedoman replanting tersebut, yang mana pihak koperasi unit desa memberi keluasaan kepada masyarakatnya untuk menjual buat tandan sawit ketengkulak sawit masing-masing, pihak koperasi unit desa hanya memantau dalam pertumbuhan sawitya.

\section{Upaya Pemerintah Koperasi Unit Desa (KUD) Citra Markadi Dalam Pelaksanaan (Replanting) Perkebunan Kelapa Sawit Di Dusun Lembah Kuamang Tahun 2019.}

Dalam pelaksanaan peremajaan perkebunan kelapa sawit di dusun lembah kuamang tidak terealisasi dengan baik di karenakan tidak mengikuti dalam prosedur yang sudah di tetapkan dalam pedoman peremajaan perkebunan kelapa sawit No 18 Tahun 2016 tentang pelaksanaan peremajaan (replanting) perkebunan kelapa sawit. Yang mana pelaksanaan peremajaan perkebunana kelapa sawit tidak terealisasi dengan baik terdapat dalam pasal 2, pasal 4 dan pasal 6 hal ini yang menimbulakan permasalahan dalam pelaksanaan peremajaan tersbut. Adapun upaya pemerintah Koperasi Unit Desa (KUD) dalam menyelesaikan permasalahan yang sedang terjadi didusun lembah kuamang kecamatan pelapat ilir kabupaten bungo KUD Citra Markadi sebagai berikut:

1. Pihak Koperasi Unit Desa (KUD) Citra Markadi melaporkan permasalahan ini kepada pihak dinas pertanian yang bertanggung jawab dalam pelaksanaan peremajaan perkebuan kelapa sawit. Dalam hal ini setelah pihak Koperasi Unit Desa bersosialisasi dengan pihak dinas pertanian dalam menangani peramasalahan ini pihak Koperasi Unit Desa diharapkan untuk bersabar terlebih dahulu memberikan waktu kepada pihak kontraktor dan operator tersebut.

2. Pihak koperasi unit desa (KUD) Citra Markadi sudah beberapa kali memberikan surat kepada pihak kontaraktor tetapi belum juga ada balasannya. Dalam hal ini pihak Koperasi Unit desa sudah memeberikan surat teguran yang pertama kepada pihak kontaraktor mauapun operator yang sudah beberapa minggu tidak ada tanggapan dari pihak kontraktor maupaun pihak operator. Dalam pelaksanaan peremajaan perkebunan kelapa sawit di dusun lembah kuamang target selesai pada Desember 2019 tetapi pekerjaan yang berhenti di bulan mei secara tiba-tiba yang membuat pihak koperasi unit desa kebinggungan untuk menanggapi permasalahan ini. Setelah surat teguran pertama tidak ada respon dari beberapa bulan ini maka pihak koperasi unit desa memberikan surat teguran yang ke dua kepada pihak kontaraktor maupun operator dalam hal ini dari pihak operator pun juga tidak ada tanggapn untuk surat yang kedua. Yang mana pihak koperasi unit desa bersosialisasi dengan pihak dinas pertaniaan untuk minta solusi.

3. Pihak koperasi unit desa (KUD) Citra Markadi menghubungi pihak kontaraktor dan operator. Yang mana sulitnya pihak Koperasi Unit Desa menghubungi pihak kontaraktor maupun operator, dalam pelaksanaan peremajaan perkebunan kelapa sawit di dusun lembah kuamang berhenti secara total hal ini yang menjadi kendala dalam pelaksanaan peremajaan tersebut dan terjadinya putus komunikasi antara pihak Koperasi Unit Desa dengan pihak kontaraktor maupun operator yang menyebabkan menyelesaikan masalahnya cukup lama. Seharusnya pelaksanaan peremajaan perkebunan kelapa sawit seharusntya sudah selesai di desember 2019 ini tidak sesuai dengan target yang sudah ditetapkan. 
4. Pihak koperasi unit desa (KUD) memutuskan kontrak kerja kepada pihak operator dan pihak Koperasi Unit Desa kontrak kerja dengan pihak lain. Dalam pelaksanaan peremajaan perkebunan kelapa sawit didusun lembah kuamang dimulai pada desember 2018 sampai 2019 yang seharusnya sudah selesai tetapi kenyatanya sampai sekarang belum juga selesai.

Pihak Koperasi Unit Desa (KUD) Citra Markadi sudah menunggu surat balasan dari pihak operator tetapi tidak ada tanggapan dari pihak operator maupun kontaraktor. Yang mana membuat bingung pihak koperasi unit desa dan terbengkalainya lahan masyarakan yang ikut serta dalam pelaksanaan peremajaan perkebunan kelapa sawit. Dengan hasil sosialisasi dengan pihak dinas pertanian yang mana jika pihak kontaraktor maupun operator tidak ada tanggungjawabnya maka pihak koperasi unit desa berhak untuk memutuskan kontarak dengan jangka waktu yang cukup lama dan tidak ada penyelesaian dari pihak kontaraktor mauapun operator.

Dari pihak Koperasi Unit Desa (KUD) Citra Markadi sudah memberi waktu sekitar 3 bulanan tetapi dari pihak kontraktor maupun operator tidak ada tanggungjawabanya dalam berapa bulan itu sedangkan sudah dari 11 bulan terbengkalainya lahan petani sawit didusun lembah kumanag. Yang mana pihak koperasi unit desa telah memutuskan kontarak kerja pada April 2020 kepada pihak operator dan pihak Koperasi Unit Desa mengontarak kerja dengan pihak operator lain.

Ketua koperasi unit desa (KUD) Citra Markadi yang bertanggungjawab dalam pelaksanaan peremajaan (replanting) perkebunan kelapa sawit di dusun lembah kuamang. Adapun upaya yang dilakukan oleh pihak Koperasi Unit Desa (KUD) dari pihak KUD telah berkerja keras untuk menyelesaikan permasalahan dalam pelaksanaan peremajaan perkebunanan kelapa sawit didusun lembah kuamnag seperti pihak KUD sudah beberapa kali mengirimkan surat kepada pihak kontaraktor maupaun operator sampai saat ini tidak ada jawaban dari pihak kontaraktor yang membuat bingung pihak KUD dan pihak KUD datang kekantor dinas pertanian untuk menyampaikan kepada pihak dinas pertanian tentang permasalahan peremajaan perkebunanan kelapa sawit di dusun lembah kuamang. Yang mana pihak KUD di suruh sabar dalam mengatasi permasalahan tersebut apabila Desember 2019 belum selesai maka pihak KUD memutuskan kontrak kerja kepada pihak operator dan pihak KUD memberikan surat jalan untuk pengambilan bibit sawit baru tetapi dalam hal tersebut menggunakan biaya mandiri dalam pembeliaan bibit supaya masyarakat mendapatkan bibit yang berkualitas. Dalam pelaksanaan peremajaan perekbunan kaelapa sawit sharusnya sudah selesai pada desember tahun 2019 tetapi samapai tahun 2020 belum juga selesai dari pihak Koperasi Unit Desa (KUD) sudah memberikan waktu kepada pihak kontraktor maupun operator waktu yang diberikan oleh pihak koperasi unit desa sekitar tiga bulanan tetapi sampai 11 bulan belum juga selesai. Pada akhirnya dari pihak koperasi unit desa memutuskan kontarak pada mei tahun 2020 kepada pihak operator mauapun kontaktor hal ini membuat pihak koperasi unit desa harus tegas untuk mengontrak kerja dengan pihak operator lain.

\section{Penutup}

Kesimpulan dari penelitian ini adalah evaluasi berkenaan dengan produksi informasi mengenai nilai atau manfaat hasil kebijakan. Evaluasi memberi informasi yang valit dan dapat dipercaya mengenai kinerja kebijakan yaitu seberapa jauh kebutuhan, nilai, dan kesempatan telah dicapai melalui tindakan publik. Evaluasi kebijakan berkenaan pada kinerja dari kebijakan, khususnya implementasi kebijakan publik Wiliam N. Dunn (2003:608-610). Dalam pelaksanaan peremajaan perekebunan kelapa sawit didusun lembah kuamang kecamatan pelepata ilir 
kabupaten bungo. Yang mana terdapat dalam peraturan mentri pertanian Indonesia No 18 Tahun 2016 tentang pedoman pelaksanaan peremajaan perkebunan kelapa sawit. Adapun dalam peraturan mentri yang tidak terealisasi dengan baik yang terdapat dalam pasal 2 ayat 2,3, pasal 4 ayat 1 poin (a),(b) dan pasal 6 dalam hal ini yang membuat peremajaan perkebunana kelapa sawit tidak terealisasi dengan baik.

Yang mana seharusnya pedoman pelaksanaan peremajaan perkebunan kelapa sawit bisa menjadi pedoman dalam pelaksanaan tersebut supaya berjalannya pelaksanaan peremajaan tersebut dengan baik. Dalam pelaksnaa peremajaan perkebunan kelapa sawit didusun lembah kuamang pertama dimulai pada desember tahun 2018 target tahun 2019 selesai tahun 2020 belum juga selesai hal ini yang memebuat petani sawit menjadi bingung dalam keadaan ini dari pihak koperasi unit desa (KUD) seharus menyampaikan kepada pihak petani sawit tetapi tidak adanya sosialisasi kepada petani sawit hal ini yang memebuat petabi bingung. Yang mana dalam pelaksanaan peremajan perkebunan kelapa sawit ini di biayai oleh Badan Pengelolahan Dana Perkebunan Kelapa Sawit (BPDPKS) dalam hal ini pemerintah memberikan manfaat bagai hasil pajak CPO dari hasil pajak tersebut yang bisa membiayai masyarakat untuk mendapatkan bibit sawit yang berkualitas yang mana dari masyarakat di kembalikan untuk masyarakat.

Adapun kendala yang muncul dalam pelaksanaan peremajaan (replanting) perkebunan kelapa sawit di dusun Lembah Kuamang kecamatan Pelapat Ilir kabupeten Bungo. Yang terdapat dalam peraturan mentri pertanian Nomor 18 Tahun 2016 tentang pedoman pelaksanaan peremajaan (replanting) perkebunan kelapa sawit. Adapun dalam pedoman pelaksanaan peremajaan perkebunan kelapa sawit yang tidak teralisasi dengan baik yang mana terdapat dalam pasal 2 ayat 2,3, pasal 4 ayat 1 poin (a),(b) dan pasal 6 dari pasal tersebut yang membuat kendalan dalam pelaksaaan peremajaan perkebunan kelapa perkebunan kelapa sawit didusun lembah kuamang koperasi unit desa (KUD) Citra Markadi. Yang berbunyi sebagai berikut:

1. Pasal 2 ayat 2 pengembangan kelembagaan perkebun, antara lain pelatih tenaga pendamping dan pekebun, penguatan organisasi, manajemen dan taat kelola kelompok tani/gabungan kelompok tani/koperasi, peningkatan kerjasama, dan kemitraan usaha dan

2. Pasal 2 ayat 3 unsur pendukung, antara lain pemetaan, Surat Tanda Daftar Usaha Perkebunan untuk Budidaya (STD-B), surat persyaratan pengelolahan lingkungan, sertifikasi lahan dan sertifikasi ISPO bagi yangmemenuhi syarat aturan dan perundang-undang.

3. $\quad$ Pasal 4 ayat 1 poin (a) tenaga kerja

4. Pasal 4 ayat 1 poin (b) bahan dan alat

5. Pasal 6 yang berbunyi peremajaan perkebunan kelapa sawit dapat dilakukan dengan melanjutkan pola kemitraan yang telah ada maupun pola lainya dalam hubungan yang saling menguntungkan, salig menghargai, saling bertanggung jawab, saling memperkuat dan saling ketergantungan.

Sebagaimana telah disampaikan diatas bawasanya didusun lembah kuamang yang belum terealisasi dengan baik, dalam kegiatan peremajan perkebunan kelapa sawit seharusnya mengikuti peraturan yang sudah ditetapkan oleh mentri pertanian yang ada dipedoman peremajaan perkembukan kelapa sawit. Yang mana dalam pelaksaaan peremajaan perkebunan kelapa sawit harus memenuhi prosedur yang sudah di tetapkan, dari pihak koperasi unit desa (KUD) seharusnya pengembangan kelembagaan perkebunan seperti penguatan organisasi dan bergabung dengan kelompok tani yang ada di dusun lembah kuamang supaya ada kemitraan dengan pihak koperasi unit desa. Yang mana dapat menguntungkan dua 
belah pihak, untuk mengikuti pelaksanaan peremajaan perkebunan kelapa sawit harus memenuhi persyaratan yang sudah ditetapkan oleh pemerintah daerah.

Adapun upaya yang dilakukan oleh pihak Koperasi Unit Desa (KUD) dalam menyelesaikan permasalahan yang sedang terjadi didusun lembah kuamang Koperasi Unit Desa (KUD) Cirta Markadi, upaya yang dilakukan oleh koperasi unit desa memberikan teguran kepada pihak kontaraktor maupun operator dari pihak KUD memberikan waktu yang cukup lama untuk pihak kontaraktor maupun operator tetapi tidak ada jawabaan dari pihak operator. Yang mana dari pihak Koperasi Unit Desa telah memberikan surat kepada pihak kontaraktor maupun operator tetapi tidak ada tangapan dari pihak kontaraktor maupaun operator, dalam hal ini yang membuat pihak koperasi unit desa memutuskan kontarak kepada pihak operator dan membuat pihak koperasi unit desa mengontrak kerja dengan pihak lain.

Saran dari penulis Setelah penyusun menganalisis penelitian dari hasil penelitian dilapangan, maka penyusun dapat memberi saran-saran yang diharapkan dapat membangun atau memperbaiki keadaan yang sudah ada, adapun saran-saran sebagai berikut: 1) Seharusnya pemerintah Koperasi Unit Desa (KUD) lebih cepat lagi dalam penangani permasalahan peremajaan perkebunan kelapa sawit. 2) Seharusnya pihak kontraktor lebih bertanggung jawab atas perkerjaannya dalam pelaksanaan peremajaan (replanting) perkebunan kelapa sawit supaya pelaksanaan replanting tersebut berjalan dengan lancar. 3) Seharunya dalam menagatasi permasalahan dalam pelaksanaan peremajaan perkebunan sawit ini seharusnya pihak Koperasi Unit Desa (KUD) Citra Markadi bersosialisasi dengan masyarakatnya supaya tidak terjadinya kesalah pahaman.

\section{Referensi}

Abidin, Zainal Said. (2012). Kebijakan Publik. Salemba Humanika

bppd. (2019). "Program Peremajaan sawit." hhtp://www.bpdp.or.id/id/tag

Hakim, M., \& Suherman, C. (2018). Replanting Kelapa Sawit, Penebar Swadaya. Penebar Swadaya.

Hutasoit, F. R., Hutabarat, S., \& Muwardi, D. (2015). Analisis persepsi petani kelapa sawit swadaya bersertifikasi rspo dalam menghadapi kegiatan peremajaan perkebunan kelapa sawit di Kecamatan Ukui Kabupaten Pelalawan. Riau University.

Indiahono, Dwiyanto. (2017). Kebijakan Publik. Gava Media.

Pemerintah Republik Indonesia. (2015). Peraturan Presiden Nomor 61 Tahun 2015 Tentang

Penghimpunan Dan Pengelolahan Dana Perkebunan Kelapa Sawit.

http://www.bpdp.or.id/id

Pertanian, K. (2016). Peraturan Mentri Pertanian RI 18 tahun 2016 tentang pedoman

Peremajaan Perkebunan kelapa sawit. http://www.bpdp.or.id/id/

Rianse, Usman dan Abdi. (2008). Metodologi penelitian sosial dan ekonomi. Alfabeta:

Saputri, E., \& Syafrizal, S. (2018). Kesiapan Petani Kelapa Sawit dalam Menghadapi Peremajaan

Kebun (Replanting) di Kampung Delima Jaya Kecamatan Kerinci Kanan Kabupaten Siak. Riau University.

Subagyo, Joko. (2011). Metode Penelitian Dalam Teori Dan Praktik. Rineka Cipta.

Ulber, Silalahi. (2009). Metode Penelitian Sosial. Refika aditama. 